\title{
Anthropometry of elderly residents in the city of São Paulo, Brazil
}

\author{
Antropometria em idosos \\ no Município de São Paulo, Brasil
}

\author{
1 Programa Interunidades \\ em Nutrição Humana \\ Aplicada, Universidade de \\ São Paulo, São Paulo, Brasil. \\ 2 Departamento de Saúde, \\ Universidade Estadual \\ do Sudoeste da Bahia, \\ Jequié, Brasil. \\ 3 Faculdade de Saúde \\ Pública, Universidade de \\ São Paulo, São Paulo, Brasil. \\ Correspondência \\ A. R. Barbosa \\ Programa Interunidades em \\ Nutrição Humana Aplicada, \\ Universidade de São Paulo. \\ Av. José Cândido da Silveira \\ 121, apto. 102, \\ Belo Horizonte, $M G$ \\ 31170-000, Brasil. \\ alinerb13@yahoo.com.br
}

\author{
Aline R. Barbosa 1 \\ José M. P. Souza 3 \\ Maria L. Lebrão ${ }^{3}$ \\ Ruy Laurenti 3 \\ Maria de Fátima N. Marucci ${ }^{3}$
}

\section{Introduction}

The elderly population ( $\geq 60$ years) is growing rapidly in the Latin American and Caribbean countries. In Brazil, according to data from the latest census, the proportion of older adults was $8.6 \%$ (14.5 million) in 2000 (Instituto Brasileiro de Greografia e Estatística. Censo Demográfico: Resultados Preliminares. http://www. ibge.gov.br/estatistica/populacao/censo2000/ destaque.shtm, accessed on Jul/2003), and the forecast is that by 2025 the elderly will represent $15.0 \%$ of the total Brazilian population 1 .

Assessment of nutritional status is helpful for understanding the health of older people. In clinical practice and epidemiological studies, anthropometry is the most widely used method, since it is non-invasive, economical, and easily applied 2,3,4,5,6,7.

There is little anthropometric information available on the elderly, especially in developing countries, and only more recently have population studies included specific data on individuals 75 years of age and older 4,5,6,7.

The World Health Organization (WHO) 8 emphasizes the need for population-specific reference values. The data should be presented as gender-specific means (with standard deviations) and percentiles for each measurement or index 9.

In Brazil, anthropometric data for the elderly are limited to measurements of body mass, 
height, and body mass index (BMI = weight/ height 2 ), from the National Health and Nutrition Survey (PNSN/1989) 3,8, and research by Barreto et al. 10 (BMI) and Menezes 11 (BMI, triceps skinfold thickness, and arm muscle circumference).

The principal objectives of the present study were: (a) to present distribution values for anthropometric characteristics based on a crosssectional (representative) sample for non-institutionalized older adults residing in the city of São Paulo, Southeast Brazil and (b) to describe the age and gender differences in order to identify variations in anthropometric characteristics of the elderly.

\section{Methods}

This was an epidemiological cross-sectional, household-based study, part of the Survey on Health and Well-being of the Elderly-SABE (in Brazil, Saúde, Bem-estar e Envelhecimento) - a multi-center study coordinated by the PanAmerican Health Organization (PAHO) and conducted in 7 countries of Latin America and the Caribbean (Argentina, Barbados, Chile, Cuba, Mexico, Uruguay, and Brazil). SABE is the first survey of its kind in the region and was simultaneously and rigorously comparable for the purpose of compiling information (Organización Panamericana de la Salud. Encuesta Multicéntrica - Salud, Bienestar y Envejecimiento (SABE) en América Latina y el Caribe - Informe Preliminar. http://www.paho.org/program/ sabe.htm, accessed on 01/Mar/2003). In Brazil this study was conducted in the city of São Paulo and coordinated by faculty members at the Faculdade de Saúde Pública, Universidade de São Paulo - FSP/USP (School of Public Health, University of São Paulo - FSP/USP).

The research questionnaire was developed by PAHO and translated and adapted for application in Brazil. Data were collected in two stages: a household interview, by a single interviewer, covering several questions on living conditions and health status of the elderly, and a household visit by a pair of interviewers 12 , including anthropometric and physical performance measurements.

The study population consisted of individuals aged 60 years and older, of both genders, residing in the city of São Paulo, during 2000 and the first quarter of 2001; anthropometric variables were collected in January-March 2001. In the first phase of the research 2,143 individuals were interviewed, and in the second phase measurements were taken from 1,894
(88.4\%) of the elderly. The main reasons for nonparticipation in the second phase were: refusal (7.5\%); address change $(2.0 \%)$; death $(1.9 \%)$; committal to an institution $(0.1 \%)$; and hospitalization $(0.1 \%)$.

Sampling procedures in SABE (Brazil component) have been reported elsewhere 13. Briefly, the sampling process consisted of two segments: (1) a probabilistic sample with 1,568 individuals, stratified by gender and age group, in which households were selected by a drawing method through two-stage grouping, using the criterion of division in proportion to the sample size; (2) 575 individuals, corresponding to the enlarged (free-composition) sample of the age group 75 years and older, for both genders, because of the lower population density of this age group, adjusted for male gender in order to offset the higher death rate among males as compared to females.

A verification procedure was used to ensure accurate real age: (a) ascertainment of the individual's age by requesting age and date of birth; (b) confirmation of reported age or date of birth with a document containing one or both (the interviewer requested to see such documents); and/or (c) verification of reported age (or date of birth) by another household member 12 .

The study was approved by the Comissão de Ética em Pesquisa, FSP/USP (Research Ethics Committee of FSP/USP) and the Comissão Nacional de Ética em Pesquisa - COEP (Brazilian National Research Ethics Committee - CONEP).

\section{Anthropometry}

Anthropometric data were obtained by health professionals and graduate students from the nutrition course who received special training including a video tape prepared by the National Institute of Nutrition of the University of Chile, aimed at standardization and better visual presentation of anthropometric techniques to be used in all countries participating in the SABE.

Body mass (BM) was measured with a SECA platform scale (Germany) up to a maximum of $150 \mathrm{~kg}$, calibrated to the nearest $0.5 \mathrm{~kg}$, with the individual barefoot and using the smallest possible amount of clothing. Height or stature (ST) was measured according to the Frisancho technique 14 , using a wall-mounted stadiometer (Harpender, UK). An appropriate place was chosen in the household such as a sturdy wall or door frame (without baseboards) that formed a right angle with the floor, without any carpet or rug. Circumferences of the waist (WC), hip (HC), arm (AC), and calf (CC) were measured 
with an inelastic measuring tape. The triceps skinfold thickness (TSF) was measured with a LANGE caliper with a constant pressure of $10 \mathrm{~g} /$ $\mathrm{mm}^{2}$. Circumferences were measured as in Callaway et al. 15 and TSF as in Harrison et al. 16. $\mathrm{AC}$, TSF, and CC were measured on the dominant side. All measurements (BM, ST, WC, HC, AC, $\mathrm{CC}$, and TSF) were taken in triplicate (same visit), and the mean values were used in the analyses.

Body mass index $\left(\mathrm{BMI}=\mathrm{kg} / \mathrm{m}^{2}\right)$ was calculated, as was arm muscle circumference (AMC = $\mathrm{AC}-p$. TSF).

\section{Statistical procedure}

Data analysis used means, standard deviations, and percentiles (5th, 10th, 25th, 50th, 75th, 90th, and 95th), in accordance with gender and age group (60-64, 65-69, 70-74, 75-79, $\geq 80$ years). Although there was no upper age limit in this study and the maximum age reported was 100 years, sample sizes of persons aged 80 years and older were limited. Thus, persons $\geq 80$ years were combined in a single age group. Age group effect was investigated by ANOVA and Tukey's test for multiple comparisons (all measurements). Determination of differences between means used the Student's $t$-test for comparison of genders in relation to BMI. Statistical significance was defined with $5 \%$ confidence intervals $(p<0.05)$. All statistical analyses used SPSS, Base 8.0.

\section{Results}

The study sample consisted of 1,124 women (59.35\%) and 770 men $(40.65 \%)$. Age varied from 60 to 100 years, with a mean of $74.2 \pm 8.4$ (SD). Mean age was $72.9 \pm 8.4$ (range 60-97) in females and $73.8 \pm 8.5$ in males $(\mathrm{p}=0.10)$.

Among the elderly in this study (1,894), 89.5\% were born in Brazil, with the $10.5 \%$ of foreignborn coming mainly from Portugal (37.4\%), Japan (21.7\%), Italy (14.6\%), and Spain (10.1\%). The largest concentration of foreign-born was in the older age groups: among individuals 75 years and older, $14.9 \%$ were immigrants, as compared to $6.47 \%$ in the $64-75$-year group. Despite obvious difference between populations according to race, Brazil displays an ethnic mix, and therefore no specific analyses for different races were performed. In the present study, when asked about their skin color/race, $70.2 \%$ self-reported as white, $12.9 \%$ mulatto, $8.2 \%$ mestizo, and the rest black, Asian, and indigenous. Census data from 2000 for urban areas in the State of São Paulo show quite similar values 12 .
Although all individuals in the SABE (São Paulo) were non-institutionalized, they were not necessarily free of co-morbidities (not analyzed in the present study). Not surprisingly for this age range, many elderly had at least one disease condition such as diabetes, hypertension, arthritis, osteoporosis, or hyperlipidemia 17.

\section{Anthropometric data}

All the measurements were taken in the individuals who were able to stand and walk, but only the AC, CC, and TSF were taken in the bed-ridden. A few measurements were not taken in some of the elderly due to their refusal or some specific incapacity.

Tables 1 and 2 show BM, ST, and BMI values (means, standard deviations, and percentiles) distributed by age group for females and males, respectively.

BM was higher $(\mathrm{p}=0.000)$ in the youngest as compared to oldest elderly in both men and women. When the oldest age group was compared to the 60-64 year group, the reduction in median BM was $13.9 \%(9 \mathrm{~kg})$ and $10.0 \%(7 \mathrm{~kg})$ for women and men, respectively. Mean BM was slightly above the median values for both genders and in all age groups. The differences ranged from 0.35 to $2.80 \mathrm{~kg}$ in women, indicating that the distribution is skewed and that mean weights are influenced by extreme values in the 65-69 age group, while for the men the means exceeded the median values by 0.12 to $1.32 \mathrm{~kg}$, showing the slight influence of extreme values.

In men, there was a height difference of $1.5 \%$ ( 1.65 SD 0.07 vs. 1.63 SD 0.08 , between the 60-64-year and 80 and older groups, respectively), and the multiple comparisons (Tukey's test) showed that the only statistically significant difference was between the 65-69 age group and the oldest individuals ( $\geq 80$ years). In women, the height difference was $3.3 \%$ (1.53 SD 0.06 vs. 1.48 SD 0.06 between the 60-64-year group and the $\geq 80$ group, respectively), with a significant difference $(p=0.000)$ between the age groups. According to the Tukey's test, there were significant differences between the oldest age group and each other group. In general, mean body weight and height in women were less than those reported for men at each age group, while median and percentile values followed the same pattern.

Mean BMI was higher $(\mathrm{p}<0.01)$ in women than in men in each age group, and it was lower in the oldest than in the youngest individuals $(p=0.000)$. Multiple comparisons showed that for women the differences were not significant between the four youngest age groups. 
Table 1

Body mass (BM), stature (ST), and body mass index (BMI) in women ( $\geq 60$ years). Survey on Health and Well-being of the Elderly (SABE), São Paulo, Brazil, 2001.

\begin{tabular}{|c|c|c|c|c|c|c|c|c|c|c|}
\hline \multirow[t]{2}{*}{ Age group (years) } & \multirow[t]{2}{*}{$\mathrm{n}$} & \multirow[t]{2}{*}{ Mean } & \multirow[t]{2}{*}{ SD } & \multicolumn{7}{|c|}{ Percentile } \\
\hline & & & & 5 & 10 & 25 & 50 & 75 & 90 & 95 \\
\hline \multicolumn{11}{|l|}{$\mathrm{BM}(\mathrm{kg})^{\star}$} \\
\hline $60-64$ & 223 & 66.37 & 13.17 & 46.60 & 50.40 & 57.00 & 65.00 & 75.50 & 82.72 & 90.72 \\
\hline $65-69$ & 204 & 63.90 & 12.75 & 45.15 & 48.00 & 55.00 & 62.00 & 71.48 & 80.00 & 88.75 \\
\hline $70-74$ & 180 & 63.30 & 13.60 & 44.00 & 46.50 & 54.13 & 60.50 & 72.38 & 83.80 & 88.48 \\
\hline $75-79$ & 235 & 61.95 & 11.83 & 44.00 & 48.00 & 54.00 & 61.60 & 70.00 & 77.00 & 83.40 \\
\hline$\geq 80$ & 229 & 57.36 & 12.14 & 37.40 & 42.00 & 49.00 & 56.00 & 64.25 & 74.00 & 79.25 \\
\hline \multicolumn{11}{|l|}{$\mathrm{ST}(\mathrm{m})^{\star}$} \\
\hline $60-64$ & 221 & 1.53 & 0.06 & 1.43 & 1.45 & 1.49 & 1.52 & 1.57 & 1.61 & 1.63 \\
\hline $65-69$ & 204 & 1.53 & 0.06 & 1.41 & 1.44 & 1.49 & 1.53 & 1.57 & 1.61 & 1.65 \\
\hline $70-74$ & 180 & 1.51 & 0.06 & 1.40 & 1.43 & 1.47 & 1.52 & 1.58 & 1.60 & 1.62 \\
\hline $75-79$ & 232 & 1.51 & 0.07 & 1.40 & 1.43 & 1.46 & 1.51 & 1.56 & 1.60 & 1.62 \\
\hline$\geq 80$ & 229 & 1.48 & 0.06 & 1.37 & 1.39 & 1.44 & 1.49 & 1.53 & 1.57 & 1.59 \\
\hline \multicolumn{11}{|l|}{ BMI $\left(\mathrm{kg} / \mathrm{m}^{2}\right)^{*}$} \\
\hline $60-64$ & $221^{\star \star}$ & 28.34 & 5.34 & 20.36 & 22.25 & 24.34 & 27.59 & 32.04 & 35.42 & 38.40 \\
\hline $65-69$ & $204^{\star \star}$ & 27.32 & 4.90 & 19.96 & 21.77 & 24.01 & 26.48 & 30.14 & 34.61 & 37.61 \\
\hline $70-74$ & $180^{\star \star}$ & 27.63 & 5.79 & 18.64 & 20.25 & 23.67 & 27.19 & 30.81 & 34.72 & 37.70 \\
\hline $75-79$ & $232^{\star \star \star}$ & 27.12 & 4.71 & 19.87 & 21.16 & 23.65 & 27.12 & 30.04 & 33.49 & 35.35 \\
\hline$\geq 80$ & $227^{\star \star}$ & 26.01 & 5.06 & 17.72 & 19.70 & 22.37 & 25.80 & 29.09 & 32.44 & 35.19 \\
\hline
\end{tabular}

${ }^{\star} p=0.000$ statistically significant difference of mean values across age groups (ANOVA);

$\star \star p=0.000$;

$\star \star \star p=0.007$ statistically significant difference of mean values between the genders (Student's t-test).

$\mathrm{SD}=$ standard deviation

The distributions (means, standard deviations, and percentiles) for CC, AC, TSF, AMC, $\mathrm{WC}$, and $\mathrm{HC}$ are shown in Tables 3 (females) and 4 (males).

TSF, AC, and AMC were significantly higher $(\mathrm{p}=0.000$ ) in the youngest elderly (in both genders). Multiple comparisons showed that for women the differences in AMC were not significant among the four youngest age groups. In men, no statistically significant differences were observed in the two youngest age groups for TSF, AMC, AC, and CC.

In men, lower WC values $(p=0.002)$ were observed in the oldest age group, although multiple comparisons showed that there was a significant difference in WC between the youngest age groups (60-64 and 65-69) and the $\geq 80$ group. For women, there were no significant differences between age groups $(p=0.076)$.

The oldest women showed lower HC ( $\mathrm{p}=$ 0.002), and multiple comparisons showed significant differences between the 60-64 group and the oldest age group ( $\geq 80$ years). In men, the reduction in $\mathrm{HC}$ with advancing age was not significant.

\section{Discussion}

This is the first population-based household survey of Brazilian elderly on the distribution of anthropometric values and nutritional indicators in the form of percentiles, specific for gender and age group. The study was conducted in a representative sample of the elderly population, suggesting that the findings can be extrapolated to the overall elderly population in the city of São Paulo. The data may be used for comparison and assessment of nutritional status in the elderly, whether in clinical practice or in epidemiological studies, except for the Brazilian elderly in general, since there are no national data for comparison. Otherwise, since they are part of an international multicenter study, the data may be compared with those from the other Latin American and Caribbean countries participating in SABE.

Anthropometry is a non-invasive, low-cost, and easily applied method, and BMI is the most frequently used indicator of nutritional status. BMI, TSF, and CC are essential components of several currently and widely-used nu- 
Body mass (BM), stature (ST), and body mass index (BMI) for men ( $\geq 60$ years). Survey on Health and Well-being of the Elderly (SABE), São Paulo, Brazil, 2001.

\begin{tabular}{|c|c|c|c|c|c|c|c|c|c|c|}
\hline \multirow{2}{*}{ Age group } & \multirow[t]{2}{*}{$\mathrm{n}$} & \multirow{2}{*}{ Mean } & \multirow[t]{2}{*}{ SD } & \multicolumn{7}{|c|}{ Percentile } \\
\hline & & & & 5 & 10 & 25 & 50 & 75 & 90 & 95 \\
\hline \multicolumn{11}{|l|}{$\mathrm{BM}(\mathrm{kg})^{\star}$} \\
\hline $60-64$ & 155 & 70.80 & 13.26 & 50.80 & 55.80 & 62.40 & 70.00 & 78.50 & 85.96 & 92.50 \\
\hline $65-69$ & 104 & 71.22 & 12.81 & 52.00 & 57.00 & 63.63 & 69.90 & 77.75 & 86.80 & 89.25 \\
\hline $70-74$ & 108 & 68.43 & 12.00 & 48.73 & 52.00 & 61.00 & 68.75 & 75.88 & 85.50 & 90.46 \\
\hline $75-79$ & 181 & 67.71 & 12.50 & 48.07 & 51.00 & 58.25 & 66.60 & 76.00 & 84.84 & 90.90 \\
\hline$\geq 80$ & 186 & 62.88 & 11.50 & 44.18 & 47.94 & 54.00 & 63.00 & 71.62 & 78.50 & 82.30 \\
\hline \multicolumn{11}{|l|}{ ST $(m)$} \\
\hline $60-64$ & 155 & 1.65 & 0.07 & 1.54 & 1.57 & 1.61 & 1.65 & 1.70 & 1.75 & 1.78 \\
\hline $65-69$ & 104 & 1.66 & 0.05 & 1.57 & 1.58 & 1.61 & 1.65 & 1.70 & 1.74 & 1.77 \\
\hline $70-74$ & 109 & 1.64 & 0.07 & 1.51 & 1.55 & 1.60 & 1.64 & 1.70 & 1.74 & 1.76 \\
\hline $75-79$ & 180 & 1.64 & 0.06 & 1.54 & 1.56 & 1.60 & 1.64 & 1.69 & 1.74 & 1.76 \\
\hline$\geq 80$ & 185 & 1.63 & 0.08 & 1.52 & 1.54 & 1.59 & 1.62 & 1.68 & 1.72 & 1.75 \\
\hline \multicolumn{11}{|l|}{ BMI $\left(\mathrm{kg} / \mathrm{m}^{2}\right)^{\star}$} \\
\hline $60-64$ & $155^{\star}$ & 25.81 & 4.28 & 19.32 & 20.95 & 23.53 & 25.64 & 27.83 & 29.88 & 34.09 \\
\hline $65-69$ & $104^{*}$ & 25.92 & 3.92 & 19.06 & 20.42 & 23.94 & 25.67 & 28.21 & 30.61 & 31.09 \\
\hline $70-74$ & $108^{*}$ & 25.39 & 4.11 & 18.58 & 20.30 & 22.65 & 25.11 & 28.57 & 30.41 & 31.64 \\
\hline $75-79$ & $180^{\star \star \star}$ & 25.01 & 3.95 & 18.53 & 19.90 & 22.27 & 25.09 & 27.56 & 30.47 & 31.97 \\
\hline$\geq 80$ & $185^{\star}$ & 23.58 & 3.70 & 17.56 & 18.83 & 21.14 & 23.41 & 26.24 & 28.44 & 29.75 \\
\hline
\end{tabular}

${ }_{*}^{*} p=0.000$ statistically significant difference of mean values across age groups (ANOVA);

$\star * p=0.000$;

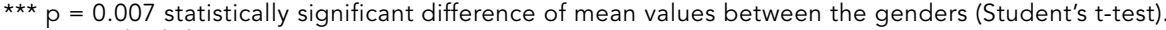

$\mathrm{SD}=$ standard-deviation.

tritional screening instruments developed for the elderly, such as the Nutritional Risk Index 18 and Mini Nutritional Assessment 19 . The AMC and CC, which estimate muscle reserve (the former estimate arm muscle tissue and the latter leg muscle), are considered good indicators of undernourishment in the elderly, and CC has been recommended as a sensitive measurement of muscle mass loss in this age group 8 . WC has been used to identify possible visceral adiposity and risk of cardiovascular diseases and metabolic disorders 20.

The results, as in other studies 4,5,6,7, showed higher mean BM and height values for men, as expected. Lower height values in women and older age groups can be explained by some factors such as loss of muscle tone and greater muscle contraction, in addition to alterations in inter-vertebral discs, vertebral bodies, and posture, which can be greater in women as a result of more frequent osteoporosis 8 . When the elderly in São Paulo were asked, "Has a doctor or health professional said that you have osteoporosis?", the answer was positive for $14.2 \%$ of the 2,143 interviewees in the first phase of the research, including $22.3 \%$ of women and $2.7 \%$ of men 17 .

Also important are the effects of differences between cohorts and the secular height trend, which may reflect influences existing from the intrauterine period until the end of development, when improvements in living conditions and population health may have affected men and women differently. According to the WHO 8 , in the developed countries the positive secular height trend was more evident in men than women, but the same cannot be stated for the elderly in the current study.

A comparison of data from the National Health and Nutrition Survey (PNSN/1989) 8 shows a slight height difference $(0.5$ to $1 \mathrm{~cm})$ between genders in the same age groups (60-69 and 70-79), with higher values in the elderly in the current study. This height increase may reflect cultural differences and improved quality of health and nutritional status in the population, and it may also have resulted from sampling differences, since the PNSN covered individuals from the various regions of Brazil, with different socioeconomic and cultural characteristics. 
Anthropometric values for women ( $\geq 60$ years). Survey on Health and Well-being of the Elderly (SABE), São Paulo, Brazil, 2001.

\begin{tabular}{|c|c|c|c|c|c|c|c|c|c|c|}
\hline \multirow[t]{2}{*}{ Age group } & \multirow[t]{2}{*}{$\mathrm{n}$} & \multirow[t]{2}{*}{ Mean } & \multirow[t]{2}{*}{ SD } & \multicolumn{7}{|c|}{ Percentile } \\
\hline & & & & 5 & 10 & 25 & 50 & 75 & 90 & 95 \\
\hline \multicolumn{11}{|c|}{ Arm circumference $(\mathrm{cm})^{*}$} \\
\hline $60-64$ & 227 & 32.42 & 3.88 & 26.00 & 28.00 & 30.00 & 33.00 & 35.00 & 37.00 & 39.00 \\
\hline $65-69$ & 210 & 31.12 & 4.03 & 25.00 & 27.00 & 28.00 & 31.00 & 34.00 & 36.00 & 38.45 \\
\hline $70-74$ & 185 & 31.35 & 4.78 & 24.00 & 25.00 & 28.00 & 31.00 & 34.00 & 37.00 & 40.00 \\
\hline $75-79$ & 242 & 30.87 & 4.30 & 24.00 & 26.00 & 28.00 & 31.00 & 33.00 & 36.00 & 38.00 \\
\hline$\geq 80$ & 256 & 28.56 & 4.27 & 22.00 & 23.00 & 26.00 & 29.00 & 31.00 & 34.00 & 35.15 \\
\hline \multicolumn{11}{|c|}{$\begin{array}{l}\text { Arm muscle } \\
\text { circumference }(\mathrm{cm})^{\star}\end{array}$} \\
\hline $60-64$ & 224 & 23.24 & 2.62 & 18.77 & 19.89 & 21.46 & 23.21 & 24.94 & 26.32 & 28.14 \\
\hline $65-69$ & 210 & 22.99 & 2.64 & 19.00 & 20.09 & 21.14 & 22.55 & 24.66 & 26.19 & 27.85 \\
\hline $70-74$ & 180 & 22.71 & 2.74 & 18.49 & 19.22 & 21.02 & 22.52 & 24.43 & 26.32 & 28.11 \\
\hline $75-79$ & 238 & 22.83 & 2.57 & 18.52 & 19.70 & 21.03 & 22.82 & 24.46 & 25.89 & 27.06 \\
\hline$\geq 80$ & 249 & 21.97 & 2.41 & 18.17 & 18.86 & 20.31 & 22.01 & 23.62 & 24.78 & 25.96 \\
\hline \multicolumn{11}{|c|}{$\begin{array}{l}\text { Triceps skinfold } \\
\text { thickness }(\mathrm{mm})^{*}\end{array}$} \\
\hline $60-64$ & 224 & 28.85 & 7.71 & 17.00 & 20.00 & 23.00 & 29.00 & 35.00 & 39.00 & 72.00 \\
\hline $65-69$ & 210 & 25.88 & 7.31 & 15.00 & 17.00 & 20.75 & 26.00 & 30.00 & 35.00 & 38.00 \\
\hline $70-74$ & 180 & 26.61 & 8.67 & 11.05 & 14.00 & 21.25 & 27.00 & 32.00 & 39.00 & 42.00 \\
\hline $75-79$ & 238 & 25.25 & 8.14 & 11.95 & 15.00 & 20.00 & 25.00 & 30.00 & 37.00 & 39.00 \\
\hline$\geq 80$ & 249 & 20.35 & 7.48 & 8.00 & 10.00 & 15.00 & 20.00 & 25.50 & 30.00 & 33.50 \\
\hline \multicolumn{11}{|c|}{ Calf circumference $(\mathrm{cm})^{*}$} \\
\hline $60-64$ & 225 & 36.85 & 4.21 & 31.00 & 32.00 & 34.00 & 36.00 & 40.00 & 42.00 & 44.00 \\
\hline $65-69$ & 209 & 35.86 & 4.04 & 29.50 & 31.00 & 33.0 & 36.00 & 38.00 & 41.00 & 42.00 \\
\hline $70-74$ & 184 & 35.76 & 4.07 & 29.00 & 30.00 & 33.00 & 36.00 & 39.00 & 41.00 & 42.00 \\
\hline $75-79$ & 241 & 34.95 & 3.90 & 29.00 & 30.00 & 32.00 & 35.00 & 37.50 & 40.00 & 41.00 \\
\hline$\geq 80$ & 255 & 33,57 & 4.05 & 27.00 & 28.00 & 31.00 & 34.00 & 36.00 & 38.00 & 41.00 \\
\hline \multicolumn{11}{|c|}{ Waist circumference $(\mathrm{cm})$} \\
\hline $60-64$ & 224 & 94.58 & 14.01 & 73.00 & 76.00 & 85.00 & 94.00 & 104.00 & 110.00 & 120.50 \\
\hline $65-69$ & 205 & 91.86 & 13.12 & 71.00 & 75.60 & 83.00 & 91.00 & 100.00 & 110.00 & 114.00 \\
\hline $70-74$ & 180 & 95.21 & 14.71 & 70.50 & 76.10 & 84.00 & 96.00 & 105.75 & 113.80 & 118.00 \\
\hline $75-79$ & 232 & 94.92 & 12.75 & 75.65 & 78.00 & 86.00 & 94.50 & 104.00 & 111.00 & 114.35 \\
\hline$\geq 80$ & 228 & 93.32 & 13.66 & 70.00 & 74.00 & 84.00 & 94.00 & 102.00 & 110.00 & 116.00 \\
\hline \multicolumn{11}{|c|}{ Hip circumference $(\mathrm{cm})^{\star *}$} \\
\hline $60-64$ & 224 & 105.58 & 11.63 & 89.00 & 92.50 & 98.00 & 104.00 & 113.00 & 122.00 & 129.00 \\
\hline $65-69$ & 205 & 103.80 & 10.73 & 89.00 & 91.00 & 97.00 & 102.00 & 111.00 & 118.00 & 123.00 \\
\hline $70-74$ & 180 & 104.64 & 11.98 & 87.00 & 91.00 & 96.00 & 103.00 & 112.00 & 121.90 & 126.95 \\
\hline $75-79$ & 232 & 103.45 & 10.53 & 86.00 & 90.00 & 96.00 & 102.00 & 109.00 & 118.70 & 122.00 \\
\hline$\geq 80$ & 228 & 101.39 & 11.14 & 84.45 & 87.00 & 94.00 & 101.00 & 107.00 & 117.00 & 120.55 \\
\hline
\end{tabular}

$* p=0.000$

$\star * p=0.002$ statistically significant difference of mean values across age groups (ANOVA).

$\mathrm{SD}=$ standard-deviation 
Anthropometric values for men ( $\geq 60$ years). Survey on Health and Well-being of the Elderly (SABE), São Paulo, Brazil, 2001.

\begin{tabular}{|c|c|c|c|c|c|c|c|c|c|c|}
\hline \multirow[t]{2}{*}{ Age group } & \multirow[t]{2}{*}{$\mathbf{n}$} & \multirow[t]{2}{*}{ Mean } & \multirow[t]{2}{*}{ SD } & \multicolumn{7}{|c|}{ Percentile } \\
\hline & & & & 5 & 10 & 25 & 50 & 75 & 90 & 95 \\
\hline \multicolumn{11}{|c|}{ Arm circumference $(\mathrm{cm})^{\star}$} \\
\hline $60-64$ & 157 & 30.50 & 3.42 & 24.90 & 27.00 & 29.00 & 30.00 & 32.00 & 35.00 & 37.00 \\
\hline $65-69$ & 110 & 30.55 & 3.72 & 24.55 & 27.00 & 29.00 & 30.00 & 32.00 & 34.90 & 36.00 \\
\hline $70-74$ & 114 & 29.58 & 3.28 & 24.00 & 26.00 & 27.00 & 30.00 & 32.00 & 34.00 & 35.25 \\
\hline $75-79$ & 189 & 28.90 & 3.45 & 23.00 & 24.00 & 26.00 & 29.00 & 31.00 & 33.00 & 35.00 \\
\hline$\geq 80$ & 199 & 27.42 & 3.30 & 22.00 & 23.00 & 25.00 & 28.00 & 30.00 & 32.00 & 33.00 \\
\hline \multicolumn{11}{|c|}{$\begin{array}{l}\text { Arm muscle } \\
\text { circumference }(\mathrm{cm})^{\star}\end{array}$} \\
\hline $60-64$ & 154 & 25.57 & 2.65 & 20.74 & 21.97 & 23.86 & 25.60 & 27.29 & 28.82 & 29.86 \\
\hline $65-69$ & 103 & 25.53 & 2.37 & 21.18 & 22.36 & 24.12 & 25.72 & 27.17 & 28.49 & 29.20 \\
\hline $70-74$ & 103 & 24.99 & 2.51 & 20.99 & 21.77 & 23.49 & 25.03 & 26.52 & 28.19 & 28.91 \\
\hline $75-79$ & 177 & 24.60 & 2.59 & 20.34 & 21.11 & 22.79 & 24.60 & 26.32 & 28.12 & 28.73 \\
\hline$\geq 80$ & 190 & 23.52 & 2.51 & 19.15 & 20.12 & 21.65 & 23.66 & 25.49 & 26.60 & 27.41 \\
\hline \multicolumn{11}{|c|}{$\begin{array}{l}\text { Triceps skinfold } \\
\text { thickness }(\mathrm{mm})^{\star}\end{array}$} \\
\hline $60-64$ & 154 & 15.35 & 6.55 & 5.75 & 7.00 & 10.00 & 15.00 & 20.00 & 26.00 & 27.00 \\
\hline $65-69$ & 103 & 14.52 & 6.04 & 6.00 & 7.00 & 10.00 & 14.00 & 19.00 & 23.00 & 26.00 \\
\hline $70-74$ & 103 & 13.42 & 5.27 & 6.00 & 7.00 & 9.00 & 13.00 & 17.00 & 20.60 & 22.60 \\
\hline $75-79$ & 177 & 13.41 & 5.29 & 6.00 & 6.80 & 9.00 & 13.00 & 17.00 & 21.00 & 24.10 \\
\hline$\geq 80$ & 189 & 12.38 & 5.21 & 5.00 & 6.00 & 8.00 & 11.00 & 16.00 & 21.00 & 23.00 \\
\hline \multicolumn{11}{|c|}{ Calf circumference $(\mathrm{cm})^{\star}$} \\
\hline $60-64$ & 157 & 36.22 & 3.84 & 30.90 & 32.00 & 34.00 & 36.00 & 38.50 & 40.20 & 43.00 \\
\hline $65-69$ & 109 & 36.14 & 3.85 & 31.50 & 32.00 & 34.00 & 36.00 & 38.00 & 40.00 & 42.50 \\
\hline $70-74$ & 113 & 35.33 & 3.22 & 30.70 & 31.00 & 32.50 & 35.00 & 38.00 & 39.00 & 40.00 \\
\hline $75-79$ & 188 & 35.22 & 3.89 & 29.00 & 30.90 & 33.00 & 35.00 & 38.00 & 40.00 & 41.50 \\
\hline$\geq 80$ & 199 & 33.58 & 3.63 & 27.00 & 29.00 & 31.00 & 34.00 & 36.00 & 38.00 & 39.00 \\
\hline \multicolumn{11}{|c|}{ Waist circumference $(\mathrm{cm})^{\star \star}$} \\
\hline $60-64$ & 155 & 96.48 & 11.80 & 77.80 & 83.00 & 90.00 & 96.00 & 104.00 & 109.40 & 112.60 \\
\hline $65-69$ & 105 & 97.48 & 10.86 & 80.00 & 81.60 & 91.00 & 97.00 & 105.00 & 110.00 & 112.70 \\
\hline $70-74$ & 110 & 95.20 & 10.46 & 74.55 & 82.00 & 88.75 & 95.50 & 102.00 & 106.90 & 114.00 \\
\hline $75-79$ & 179 & 95.59 & 11.74 & 77.00 & 81.00 & 87.00 & 96.00 & 103.00 & 111.00 & 116.00 \\
\hline$\geq 80$ & 183 & 92.46 & 11.83 & 70.40 & 77.00 & 84.00 & 93.00 & 101.00 & 107.00 & 109.80 \\
\hline \multicolumn{11}{|c|}{ Hip circumference $(\mathrm{cm})$} \\
\hline $60-64$ & 155 & 99.75 & 9.51 & 87.00 & 91.00 & 95.00 & 99.00 & 104.00 & 109.00 & 114.80 \\
\hline $65-69$ & 105 & 99.65 & 8.65 & 88.30 & 89.60 & 94.00 & 99.00 & 104.50 & 108.40 & 113.10 \\
\hline $70-74$ & 110 & 99.11 & 7.81 & 86.00 & 91.00 & 95.00 & 99.00 & 103.00 & 109.00 & 112.00 \\
\hline $75-79$ & 180 & 99.01 & 7.90 & 88.00 & 89.00 & 93.00 & 99.00 & 103.00 & 109.90 & 113.00 \\
\hline$\geq 80 \star \star \star$ & 183 & 97.44 & 7.88 & 85.20 & 88.00 & 92.00 & 97.00 & 103.00 & 107.00 & 111.00 \\
\hline
\end{tabular}

$\star p=0.000$

${ }^{\star *} p=0.002$

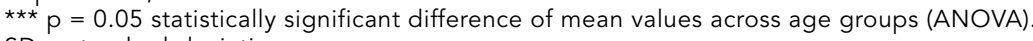

$\mathrm{SD}=$ standard-deviation. 
In the current study, age was inversely related to BM in both genders. According to some authors 4,5,6,7, this may result from selection bias, due to institutionalization or earlier death of overweight or obese individuals, a relationship that is impossible to assess in a household survey. Other factors such as reduction in total body water 8 and muscle mass (MM) appear to contribute to lower BM values in the oldest subjects. There may also be a cohort effect in the reduction of BM, since the youngest age groups were taller and thus had greater BM. A combination of all these factors may have contributed to the lower values in the more advanced age groups.

BMI was higher in women than men in all age groups and was lower in the oldest than in the youngest individuals, as shown in other studies on elderly populations 4,5,6,7,8,10. Mean BMI was greater for the elderly in São Paulo for both genders and the same age groups, as compared to results from other studies in Brazil 3,8,10,11.

Differences between BMI values in this study and those of Barreto et al. 10 for the elderly in Bambui, Minas Gerais State and Menezes 11 (Forlaleza, Ceará Sate) may be explained by socioeconomic and lifestyle differences, among others factors (Instituto Brasileiro de Greografia e Estatística. Censo Demográfico: Resultados Preliminares. http://www.ibge.gov.br/estatistica/populacao/censo2000/destaque.shtm, accessed on Jul/2003).

Some observations are relevant in relation to studies on the elderly in other countries. In Santos et al. 7, from the SABE covering 1,220 elderly (60-99 years) from Santiago, Chile, BMI values for both men and women were higher than those in the elderly in São Paulo.

When the São Paulo BMI values are compared with the data from the third National Health and Nutrition Examination Survey (NHANES III) for elderly in the United States 4, American males and females (all racial/ethnic groups combined) show similar BMI values, unlike those observed in the present study. Percentile values for American elderly males of all the age groups were higher than those in the present study, suggesting more obesity in these individuals, while women from the two countries showed similar values.

Arm circumference values in the Brazilian study, which were higher among women, appear to indicate greater subcutaneous fat, given that women presented higher TSF values and lower AMC. Comparison of AC, TSF, and AMC in the 60-64 and $\geq 80$ age groups may suggest that the oldest women undergo a greater reduction in subcutaneous fat, while the oldest men present greater loss of MM.
When the results of the São Paulo study (AC, TSF, and AMC) were compared with data from NHANES III 4, elderly American women showed similar values (means and percentiles) for AC, lower TSF, and higher AMC in all age groups. For men, mean values and percentiles for TSF were higher in the Brazilian elderly, while the Americans showed higher AC and AMC, suggesting less subcutaneous fat and more MM in the Americans (both genders).

Anthropometric comparison of different populations should be viewed with caution, because normal effects of aging result from both exogenous factors and genetic differences. AC and TSF may also be difficult to interpret, because apparent changes in measurements may reflect differences in compressibility of skin and subcutaneous tissue due to tissue hydration and redistribution of fat mass from subcutaneous to internal sites, mainly intra-abdominal accumulation of fat.

Based on risk indicators for cardiovascular disease and metabolic disorders (WC $\geq 88$ and 102 for women and men, respectively) 20, WC data from this study indicate that in São Paulo approximately $25.0 \%$ and $50.0 \%$ of elderly men and women, respectively, from all age groups may be at risk. Compared to Italian seniors 5, the percentage of individuals at risk was similar for males and females in São Paulo, based on WC. However, these figures should be interpreted with caution, since data on the elderly are still scarce and it is not clear whether they present the same risks as younger individuals.

The results showed significant age-related anthropometric differences in both men and women aged 60 years and older. However, the survey has limitations inherent to cross-sectional studies, such as cohort effect and secular trend, which interfere in the interpretation of age-related differences and alterations due to aging, although the results are consistent with longitudinal findings 2 . The study also fails to allow assessment of individual anthropometric changes.

Despite such limitations, the data suggest the occurrence of alterations in body dimensions, differentiated by gender. The oldest individuals showed a thinner body frame than the youngest (in both genders). The alterations were greater in the older age group, although it should be said that the latter was also the most heterogeneous group.

Long-term longitudinal studies can quantify and determine the anthropometric alterations that occur with aging. Other studies (including cross-sectional) should be performed with samples representing the elderly from the different regions of Brazil. 


\section{Resumo}

O artigo apresenta dados antropométricos selecionados, específicos para gênero e idade, de uma amostra representativa de idosos no Município de São Paulo, Brasil. A metodologia adotada foi de um inquérito domiciliar transversal. Foram examinados 1.894 idosos (de ambos os sexos, $\geq 60$ anos) entre janeiro e março de 2001. Os dados foram apresentados como médias e percentis de massa corporal; estatura; Índice de Massa Corporal (IMC); circunferência de cintura, quadril, braço e panturrilha; espessura da dobra cutânea do tríceps e circunferência do músculo do braço, e foram descritas as diferenças de acordo com idade (para todas as variáveis) e gênero (IMC). Com exceção da circunferência do quadril (em homens), todas as variáveis antropométricas eram mais baixas nos grupos mais idosos, em comparação com os mais jovens, para ambos os sexos $(p<0,01)$. O IMC era significativamente mais elevado $(p<0,01)$ nas mulheres do que nos homens (em todas as faixas etárias). Os resultados sugerem uma perda de massa muscular e redistribuição, e redução de massa gorda com o aumento da idade (em ambos sexos). Os dados podem ser utilizados na prática clínica e nos estudos epidemiológicos baseados na interpretação de medidas antropométricas em idosos no município de São Paulo.

Antropometria; Estado Nutricional; Idoso

\section{Contributors}

The conception, planning, and data analysis/interpretation were conducted by A. R. Barbosa, J. M. P. Souza, M. L. Lebrão, R. Laurenti, and M. F. N. Marucci. A. R. Barbosa, J. M. P. Souza, and M. F. N. Marucci contributed significantly to the draft and critical review of the content. A. R. Barbosa and M. F. N. Marucci approved the final version of the manuscript.

\section{Acknowledgments}

The Brazilian component survey of SABE was supported by the São Paulo State Research Foundation (FAPESP), and the study was supported partially by a grant from the Coordinating Body for Training University-Level Personnel (CAPES).

\section{References}

1. Organización Panamericana de la Salud. Envejecimiento y salud: un cambio de paradigma. Rev Panam Salud Pública 2000; 7:60-7.

2. Hughes VA, Roubenoff R, Wood M, Frontera WR, Evans WJ, Fiatarone-Singh MA. Anthropometric assessment of 10-y changes in body composition in the elderly. Am J Clin Nutr 2004; 80:475-82.

3. Tavares EL, Anjos LA. Perfil antropométrico da população idosa brasileira. Resultados da Pesquisa Nacional sobre Saúde e Nutrição. Cad Saúde Pública 1999; 15:759-68.

4. Kuczmarski MF, Kuczmarski RJ, Najjar M. Descriptive anthropometric reference data for older Americans. J Am Diet Assoc 2000; 100:59-66.

5. Perissinotto E, Pisent C, Sergi G, Grigoletto F, Enzi G. Anthropometric measurements in the elderly: age and gender differences. Br J Nutr 2002; 87: 177-86.

6. Velasquez-Alva MC, Irigoyen CME, Zepeda ZM, Sanchez MVM, Garcia JL, Cisneros MP, et al. Anthropometric measurements of sixty-year and older Mexican urban group. J Nutr Health Aging 2003; 7:1-5.

7. Santos JL, Albala C, Lera L, Garcia C, Arroyo P, Perez-Bravo F, et al. Anthropometric measurements in the elderly population of Santiago, Chile. Nutrition 2004; 20:452-7.

8. World Health Organization. Physical status: the use and interpretation of anthropometry. Geneva: World Health Organization; 1995. (Technical Report Series 854).

9. De Onis M, Habicht JP. Anthropometric reference data for international use: recommendations from a World Health Organization Expert Committee. Am J Clin Nutr 1996; 64:650-8.

10. Barreto SM, Passos VMA, Lima-Costa MF. Obesity and underweight among Brazilian elderly. The Bambuí Health and Aging Study. Cad Saúde Pública 2003; 19:605-12.

11. Menezes TN. Estado nutricional, valor energético da alimentação dos idosos de Fortaleza/CE e sua associação com sexo, grupo etário e nível sócioeconômico [Tese de Doutorado]. São Paulo: Faculdade de Saúde Pública, Universidade de São Paulo; 2004.

12. Lebrão ML. O projeto SABE em São Paulo: uma visão panorâmica. In: Lebrão ML, Duarte YAO, organizadores. O Projeto SABE no município de São Paulo: uma abordagem inicial. Brasília: Organização Pan-Americana da Saúde; 2003. p. 35-43.

13. Peláez M, Palloni A, Albala JC, Ham-Chande R, Hennis A, Lebrão ML, et al. Survey on aging, health and wellbeing, 2000. Washington DC: Pan American Health Organization; 2003.

14. Frisancho AR. New standards of weight and body composition by frame size and height for assessment of nutritional status of adults and the elderly. Am J Clin Nutr 1984; 40:808-19.

15. Callaway WC, Chumlea WC, Bouchard C, Himes JH, Lohman TG, Martin AD, et al. Circumferences. In: Lohman TG, Roche AF, Martorell R, editors. Anthropometric Standardization Reference Manual. Champaign: Human Kinetics; 1988. p. 39-54. 
16. Harrison GG, Buskirk RE, Carter JEL, Johnston FE, Lohman TG, Pollock ML, et al. Skinfold thicknesses. In: Lohman TG, Roche AF, Martorell R, editors. Anthropometric Standardization Reference Manual. Champaign: Human Kinetics; 1988. p. 55-70.

17. Lebrão ML, Laurenti R. Condições de saúde. In: Lebrão ML, Duarte YAO, organizadores. O Projeto SABE no município de São Paulo: uma abordagem inicial. Brasília: Organização Pan-Americana da Saúde; 2003. p. 75-91.

18. Wolinsky FD. Progress in the development of a nutritional risk index. J Nutr 1990; 120:1549-51.
19. Guigoz Y, Vellas B, Garry PJ. Assessing the nutritional status of the elderly: The Mini Nutritional Assessment as part of the geriatric evaluation. Facts Research Gerontology 1994; Suppl 2:15-59.

20. Zhu S, Wang Z, Heshka S, Heo M, Faith SM, Heymsfield SB. Waist circumference and obesityassociated risk factors among whites in the third National Health and Nutrition Examination Survey: clinical action thresholds. Am J Clin Nutr 2002; 76:743-9.

Submitted on 19/May/2004

Final version resubmitted on 15/Feb/2005

Approved on 04/Mar/2005 